\title{
The Evolution of the Planning System in Poland from Sectoral to Integrated Strategic Planning
}

\author{
Judyta Wesołowska, Małgorzata Mirecka, and Tomasz Majda
}

\begin{abstract}
The paper focuses on the evolution of the planning system in Poland. Its purpose is to show the evolution from short-term planning, subordinated to the requirements of the country's economic development, to a long-term planning system, integrating various aspects of development-spatial, natural, economic, and social, taking place over the last century. The process described in the paper was largely conditioned by historical events, and the poor economic situation of the country in the post-war period and the changes taking place in the political system. The need for rapid economic development of the country dominated the planning of the interwar period (1920s and 1930s) and post-war period (1950s to 1970s), although the economic, social, and natural conditions were taken into account in 1930s spatial planning. The most complete representation of spatial integration of various planning scopes is visible in the "National Spatial Development Concept 2030," which was the main subject of the study, as the basic document concerning national spatial planning. The research demonstrates the novelty of this document in relation to previous ones. It is based on the vision of Polish space on, the development of functional areas, determined on the basis of socioeconomic and spatial features treated in a dynamic approach. The need for changes in applicable law that would allow the "National Spatial Development Concept 2030" to be implemented in planning practice is also pointed out. The material presented in the paper may form the basis for comparative studies of planning documents on a national level in various European countries.
\end{abstract}

Keywords Strategic urban-planning $\cdot$ Integrated-planning $\cdot$ Spatial-planning policy $\cdot$ Urban planning in Poland $\cdot$ Spatial planning $\cdot$ Green areas

J. Wesołowska $(\bowtie) \cdot$ M. Mirecka · T. Majda

Faculty of Architecture, Warsaw University of Technology, ul. Koszykowa 55, 00-659 Warsaw,

Poland

e-mail: judyta.wesolowska@pw.edu.pl

(C) The Author(s) 2021

A. Bisello et al. (eds.), Smart and Sustainable Planning for Cities and Regions,

Green Energy and Technology, https://doi.org/10.1007/978-3-030-57764-3_15 


\section{Introduction}

The greatest achievement of the UN World Commission on Environment and Development is defining and popularizing the idea of sustainable development. The document "Our Common Future" released in 1987 was followed by "Earth Summit 1992" in Rio de Janeiro with "Action Programme-Agenda 21" and finally "Habitat III, the United Nations Conference on Housing and Sustainable Urban Development," which took place in Quito, Ecuador, in 2016 and reinvigorated the global commitment to sustainable development, focusing on urbanization. These actions led to the acceptance of sustainable development over the last 20 years in Europe and culminated in the "Toledo Declaration" and the European Commission's report "Cities of Tomorrow-Challenges, Visions, Ways Forward" together with UE Urban Agenda and Amsterdam Pact in 2016, all of which stressed the need for a new approach to strategic regional planning.

A similar approach was already visible in pre-war Polish planning practice, but the specific evolution of the Polish development planning system is strongly determined by history. The main goal after regaining independence in 1918 was to ensure the cohesion of areas located for 123 years in partitions with completely different legal and economic systems. An integrated approach at the regional and national levels was the best opportunity for recovery-during World War I, the front passed through Polish land several times causing catastrophic destruction. The same need for cohesion followed World War II, but Poland did not get full independence until the 1990s; thus, the pre-war modern development planning system was influenced by the Russian economic approach. Attempts at integration continued but were doomed to failure.

The change in political situation in 1989 also affected the planning system. The change in the planning system was most strongly visible in the decision-making process for natural, green areas, especially in large urban regions, which faced planning challenges across different administrative jurisdictions, similar to the London Green Belt (Mace 2018). These areas on the edge of the city are the meeting point of urban and rural interests (Žlender and Ward Thompson 2017; Verdú-Vázquez et al. 2017), which in the Polish case caused a lack of proper protection and unplanned changes of the structure in both settings. The same problems appeared also in other post-communist countries in the last three decades (Boentje and Blinnikov 2007) and required a strong urban-planning process supported by clear policy acts to resolve the critical problems of urban development. The ideas of sustainable development and strategic, integrated planning are nowadays strongly visible by the goals set in almost all legal acts; the implementation of these ideas is continuously in transition to better meet the goals they lay out, with the same situation happening with all the Polish planning system. 


\section{Methodology}

The subject of the study was an analysis of provisions in the field of spatial-planning policy in Poland from the 1920s to the present day, based on selected nationallevel planning study documents. The choice of selected studies depended on their innovation and/or the importance they had in shaping the current planning system. The analysis of these studies and regulations enabled drawing conclusions for further development of planning system towards a sustainable model and the role of studies on a national level in shaping the strategic integrated planning system in Poland understood as a continuous, long-term process that integrates various functional aspects at different spatial scales.

\section{Results: Analysis of the Planning Policy System Since 1920 Until 2015 in Poland}

The analysis of the Polish planning system over the last hundred years shows a strong dependence of development process on political conditions; therefore, the analysis was divided into four periods that are characterized from this point of view.

\subsection{Planning Concepts on the National Level in 1920s and 1930s in Poland}

The initial attempts to normalize spatial planning and management processes in Poland were made after regaining independence in 1918. The first legal act regulating land development was the "Regulation of the President of the Republic of Poland of February 16, 1928, on the Construction Law and Housing Development." It unified building regulations regarding land management and rules for urban-planning preparation. Urban-planning studies were undertaken at the national level in Poland before World War II, and the need for land-use planning processes on a larger scale resulted, among other things, in changes in the construction law. In 1937, the area of the urban plan was enlarged to a voivodship level (regional) or even several voivodships, which expanded the network of regional-planning offices. In total, ten districts were established for the development of regional plans. Planning at the national level was then the subject of interest on several levels, thus focusing on various directions: urbanregional, engineering, and economic. The group of regional planners emphasized the need to construct a regional plan based on guidelines taken from the national economic and spatial plan and to create regulations for a three-stage hierarchical planning system: local, regional, and national.

The so-called engineering trend was closer to today's strategic integrated planning and identified the need to link development to the deployment of production forces 
and to consider technical and economic potential of existing resources. In 1936, the national perspective plan focused on the need to industrialize the country and level out economic differences caused by the earlier division of Poland between Russia, Prussia, and Habsburg Austria. The "National Perspective Plan" was therefore treated as an economic plan with regional transformations, yet not as a spatial development plan (Czerny 1972).

\subsection{Changes in the Planning System After World War II Until the Political Transformation of 1989}

After World War II and until the political transformation in 1989, the hierarchy principle of planning was the most popular and led Poland's planning policy system. It was introduced by the "Decree of June 2, 1946, on the Planned Development of the Country" and then consolidated in the Spatial Planning Act of 1961 and 1984. A threelevel planning system was used in which the national urban plan was at the top, and its arrangements were mandatory for regional and local plans. The Decree of 1946 did not vary significantly from other European planning standards; however, numerous loopholes allowed for decisions regarding space management to deviate from the set planning goals (Chmielewski 2006). The scope of the national plan according to the decree included the division of the country into regions; determined land-use for various needs; (1) population distribution and a network of major urban centers, (2) defining their functions, and (3) bases for development, such as transportation, power, and telecommunications network. In the first years after World War II, Poland had to deal with massive destruction and migratory movements, new borders, administrative imperfections, and a lack of basic input data for planning. Poland was largely focused on diagnosing the existing state and developing methods for elaborating the national plan. The starting point for the planning process was pre-war regional-planning concepts (especially "Warsaw Functional Concept") and theoretical systems of the Christaller's central place theory (Hsu et al. 2014). This was the basis for a prospective model of the settlement network and regionalization of the country (Toeplitz 1978) (Fig. 1). Unfortunately, due to the consolidation of the central management system and short-term planning focused on quick results in the post-war period, spatial planning implemented the state authorities' priorities, often without a connection to economic planning or the economic situation of the country (Chmielewski 2006).

From the 1950s until the1970s, the system of central governance was strongly visible in national development and departmental planning. The industry was a priority and played the main role in planning documents. The "Spatial Planning Act of 1961" maintained the hierarchy of plans and linked to economic planning even more. Regional urban planning was given a high priority, while eliminating the national urban plan - spatial planning on a national scale was carried out as part of "forward-looking plans for the development of the national economy." The purpose of spatial planning specified in the act set the stage for creating conditions to expand 


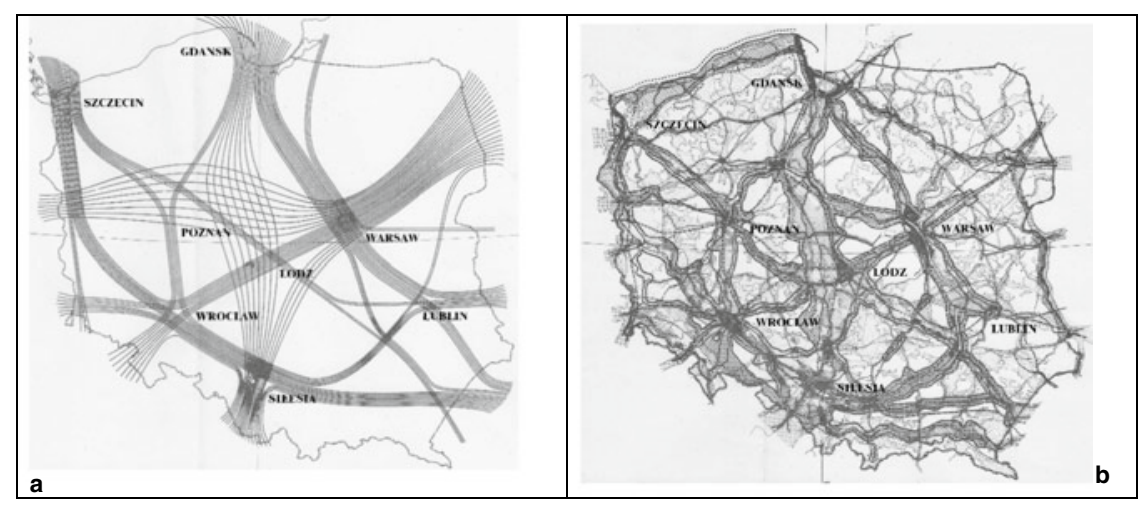

Fig. 1 The national plan of 1946 showing a development goals in urbanization net; b functional division of the country. Main development was focused in the intersection of transportation as a potential for optimal development, leaving the remaining land as rural and natural areas. Source Prepared by authors based on Toeplitz (1978)

the national production to meet the needs of the citizens and protect of the country's natural resources and its natural realm. However, the act lacked the tools to achieve these adopted goals, giving only written directives.

Despite the dominant position of socioeconomic planning from the 1950 s to 1980 s, one can also see improvements in the spatial-planning methods from this time period. The main achievements in spatial planning of these decades is the creation of new methods for analyzing development opportunities, such as Warsaw optimization and Threshold Analysis. The need for coordination of socioeconomic and spatial planning was noticed in the 1970s, which lead to the integration of the entire planning system (Secomski 1978).

The "National Spatial Development Plan until 1990" was begun in the early 1970s. At the same time, the basic assumptions for a prospective plan of the socioeconomic development of the country were made. The document was based on the interdependence of socioeconomic and spatial planning. The quantitative and qualitative assumptions were adopted from the socioeconomic development plan, mainly regarding demographics, employment, investment, and production, as well as indicators of meeting the needs of the population. The "National Spatial Development Plan" has become an extension of the socioeconomic plan by shaping settlement networks, the technical and social infrastructure grid, a basis for management of the natural environment resources and the directions of its framing, migration, urbanization processes and industrialization, and the use of agricultural/rural areas (Grabowiecki and Zawadzki 1978). Many authors referred to the importance of the plan, which focused on shaping the settlement network (Fig. 2), the goals and directions of socioeconomic policy in the regions, the development of industrial centers, the distribution of infrastructure and forming the agricultural regions (Różański 1979).

Reforms carried out in Poland in July 1975 changed the borders of its administrative regions. They introduced a new division of voivodships, decreasing their 


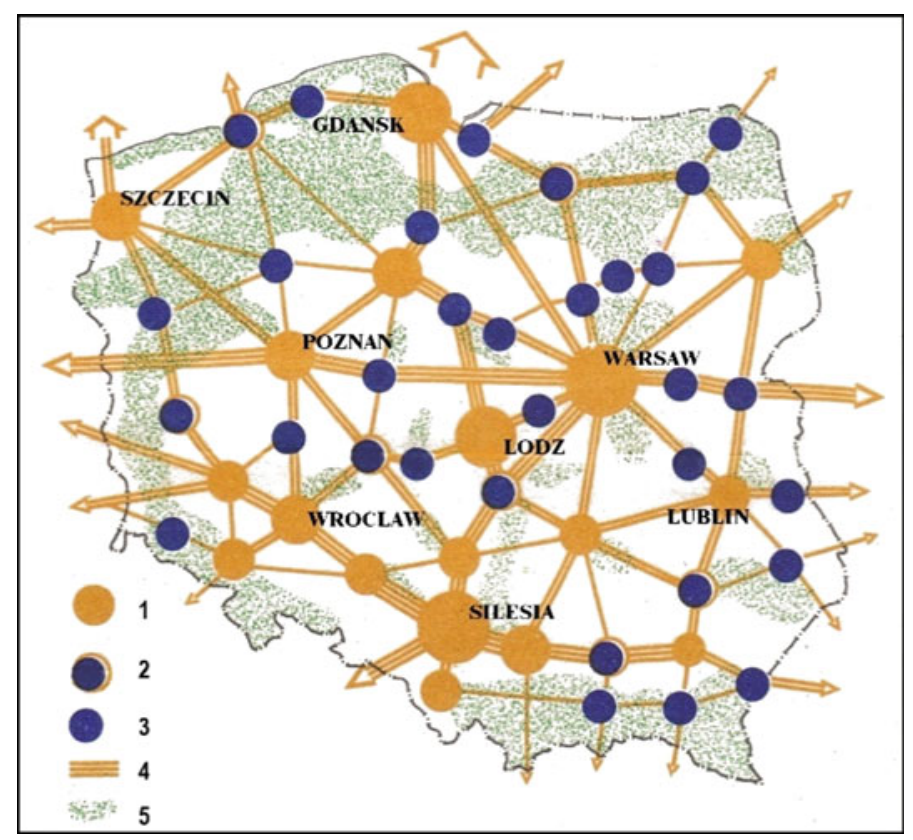

Fig. 2 Polycentric system of settlements of mitigated concentration; (1) agglomerations; (2) planned centers of development; (3) existing centers of development; (4) infrastructural connections; (5) recreation areas. Source Prepared by authors based on Grabowieck and Zawadzki (1978)

areas and dividing the country into 49 small territorial units. This helped integrate and increase the socioeconomic homogeneity of each unit. However, problems at the borders of these new units increased, and the regional plans was discontinued. Regional-tier planning departments had been closed, which caused several problems because their sphere of work also included study, diagnostic, and decision-making institutions. The scope of socioeconomic planning in the new units had been limited not only by the smaller area of planning, but also by time-only up to five years (Jędraszko 1981), thus losing the features of long-term strategic planning.

\subsection{Spatial Planning of the Political Transformation Period (1980s and 1990s)}

Changes in legal regulations regarding spatial planning in the following years were associated with adjustment to new political conditions (Borsa 2015). The transformations of the early 1980s gave more power to local governments and modifications in legal regulations followed. Because of the regional changes just mentioned, the planning system encountered significant changes. First, it was introduced by the "Spatial Planning Act of 1984," and then ten years later, in a completely new sociopolitical 
situation as the "Spatial Development Act of 1994." One of the objectives of the act from 1984 was to provide greater flexibility in spatial planning, more effectively linking prospective spatial planning with short-term socioeconomic planning. The obligatory interdependence of planning was introduced by law. The hierarchy of plans was mitigated by implementing some elements of the principle of consistency and giving lower-tier planners the right to submit applications for higher-tier plans. However, this rule did not work well in practice, and lower-tier plans continued to be adapted to those of higher-tier plans. The scope of the national plan included determining the natural, social, and economic conditions of spatial development of the country, as well as formulating the objectives and principles of spatial policy, in relation to regional diversity (Jędraszko 2005).

The "Spatial Planning Act of 1994" obliged public authorities to incorporate the economy and the significant role of local government and protection of civil and property rights in spatial planning (Fijałkowski 1994). It radically changed the comprehensive approach to planning, eliminating the regional level of planning and transferring virtually all planning power to the hands of self-governing and independent municipalities. The concept of the national spatial development policy was prepared at the national level and related to the national development strategy. On the regional tier, the regional spatial development study and government task programs were to serve the implementation of supralocal public goals. None of the mentioned studies of spatial-planning documents became applicable law, but rather played an informative and coordinating role (Kachniarz and Niewiadomski 1994). In this way, the principle of hierarchical construction of the planning system throughout the country was broken, and the only local act in the field of spatial planning became the municipal local plan. An amendment to the law on spatial development, carried out in 1999, returned the regional level of planning, which was associated with the change of regional administration borders and the new administrative division of the state. Drafted in accordance with the "Spatial Planning Act of 1994," the "Concept of the National Spatial Development Policy of 2001" was based on the so-called balanced development model, which indicated potential development areas-the nodes of efficiency, competition, innovation and entrepreneurship, and potential accelerated development directions of European, international, and national significance (Fig. 3).

Similarly to the settlement network of the polycentric mitigated concentration of the 1970s, this model referred to the band-node spatial structure of the country. The concept divided the whole country into potential development zones of ecologically driven conditions. It also defined elements considered to be stabilizing the country's development, such as metropolises, cities of European significance, and other centers for balancing development and protected areas and national and landscape parks, as well as the transport network, supralocal routes, and technical infrastructure facilities. At the same time, the NATURA 2000 network was written into the "Spatial Planning Act of 1994" with provisions on nature protection and had to be included in planning documents at all levels. The long-term view and multi-faceted connection of many areas of the country's development in one document gave the "Concept of the National Spatial Development Policy of 2001" the features of a strategic document. 


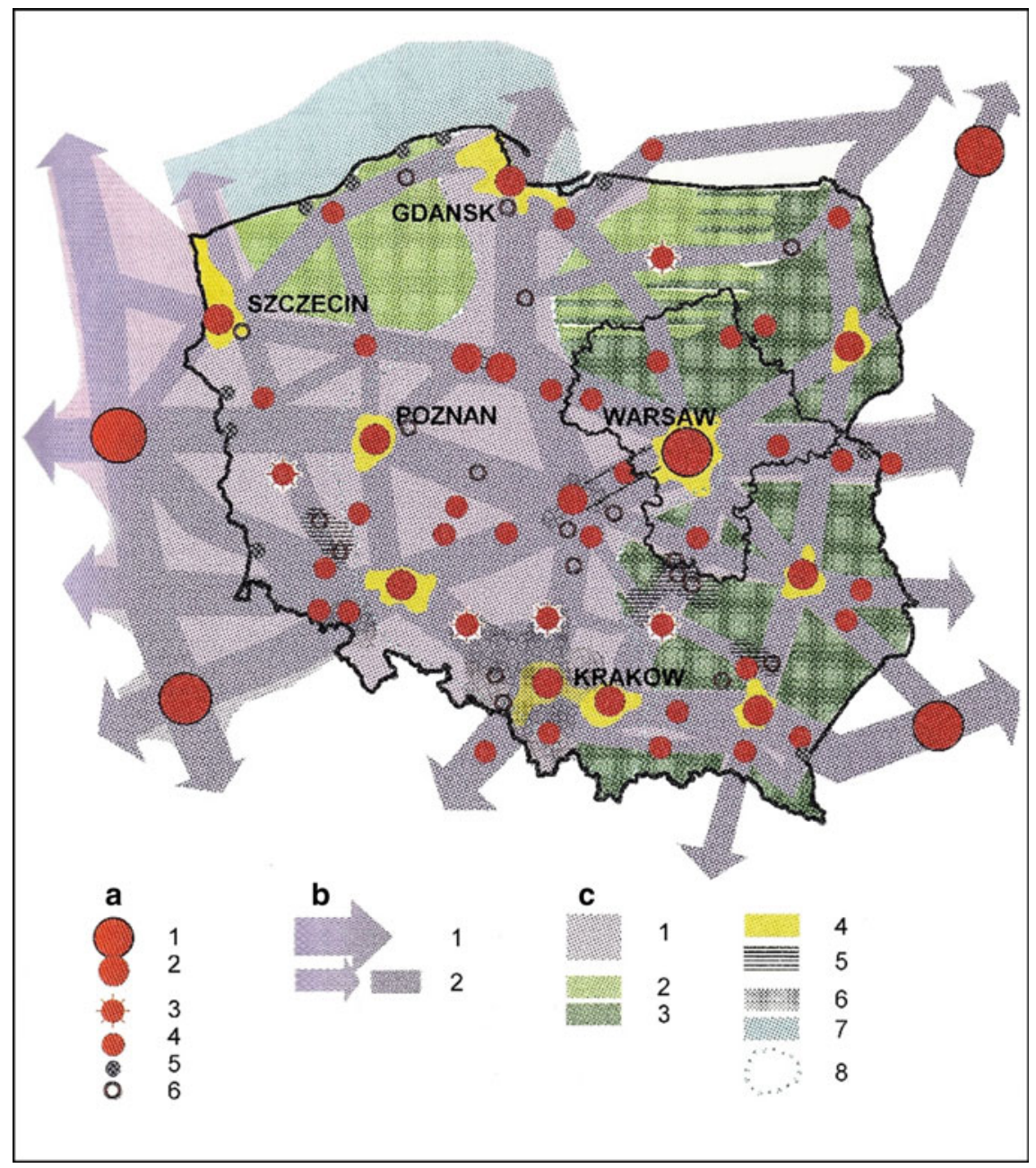

Fig. 3 Framing of the national spatial management policy—balanced development model (2001); a potential development areas-nodes of efficiency, competition, innovation, and entrepreneurship; b potential accelerated development directions shaped along with the modernization, reconstruction, and construction of the infrastructure; c potential zones of multifunctional, ecologically driven development. Source Prepared by authors based on Spatial Management Plan of the Mazovia Region, Warsaw 2004

\subsection{National Spatial Management Concept 2030}

The most important national strategic document on spatial planning is currently the “National Spatial Development Concept 2030" (NSDC 2030). This document introduced a new integrated approach to spatial planning, based on several development issues. It departs from the separate treatment of spatial and socioeconomic planning 
at the national, regional, and local level and introduces the interdependence of spatial policy objectives with the objectives of regional policy and links strategic planning with operational programming. The natural space is considered as an area where various socioeconomic, environmental, and cultural processes take place in various ways, regardless of administrative boundaries. The results of these processes vary. This approach was only possible because the authors of the NSDC 2030 departed from the previously adopted classifications, e.g., urban areas-rural areas, in favor of designating functional areas, determined by dynamically treated socioeconomic and spatial features. A vision of Polish land in 2030, based on development of functional areas, will be implemented using various instruments, one of the most important of which is spatial planning. The recommendations of those planning documents apply to national, regional, and local levels, or to spatially limited complexes, i.e., functional areas. According to this document, the national spatial development should be understood as "a way of arranging the basic elements of the spatial structure of Poland and the relations between them." The basic elements of this structure, which are the subject of analysis on the impact of public policy, include economic and social system elements, technical infrastructure, settlement network, and landscape (natural and cultural) and functional connections. The vision of NSDC 2030 strengthens five features of space: (1) competitiveness and innovation, internal cohesion consisting of integration on a local, regional, national, and international scale, (2) energy safety and natural well-being, (3) spatial order achieved through a legal system, (4) effective public institutions, and (5) biodiversity. In the last case, it was assumed that by 2030 the NATURA 2000 areas will cover over $20 \%$ of the country's area and together, with the National System of Protected Areas and ecological corridors, will form a common system of nature and landscape protection.

The integrated planning system adopted in NSDC 2030 (Fig. 4) creates good conditions for socioeconomic development, while protecting cultural and natural values, to enable coordination of development and activities at every planning level, while serving to protect the public interest. The system includes complementary elements at all planning levels. At the national level, the "National Spatial Development Concept" is maintained, alongside the "Long-Term National Development Strategy," which includes spatial elements in relation to socioeconomic elements. The "Long-Term Strategy" will be implemented through nine integrated strategies defining the basic conditions, objectives, and development directions in the areas indicated in the "Mid-Term National Development Strategy," in relation to the functional areas of the national and macro-regional level.

The typology of functional areas specified in the NSDC 2030 will primarily serve the implementation of the national and regional development objectives to minimize potential conflicts, create conditions for development, and create territorial potential. In addition to the classification of functional areas, NSDC 2030 provides features of individual types of areas and criteria for their designation, providing that their delimitation will take place at regional or local level.

An integral element of the regional development planning system, together with the strategy, will be the regional spatial development plan, which determines the coordinating role for all undertaken projects. Both documents will include plans and 


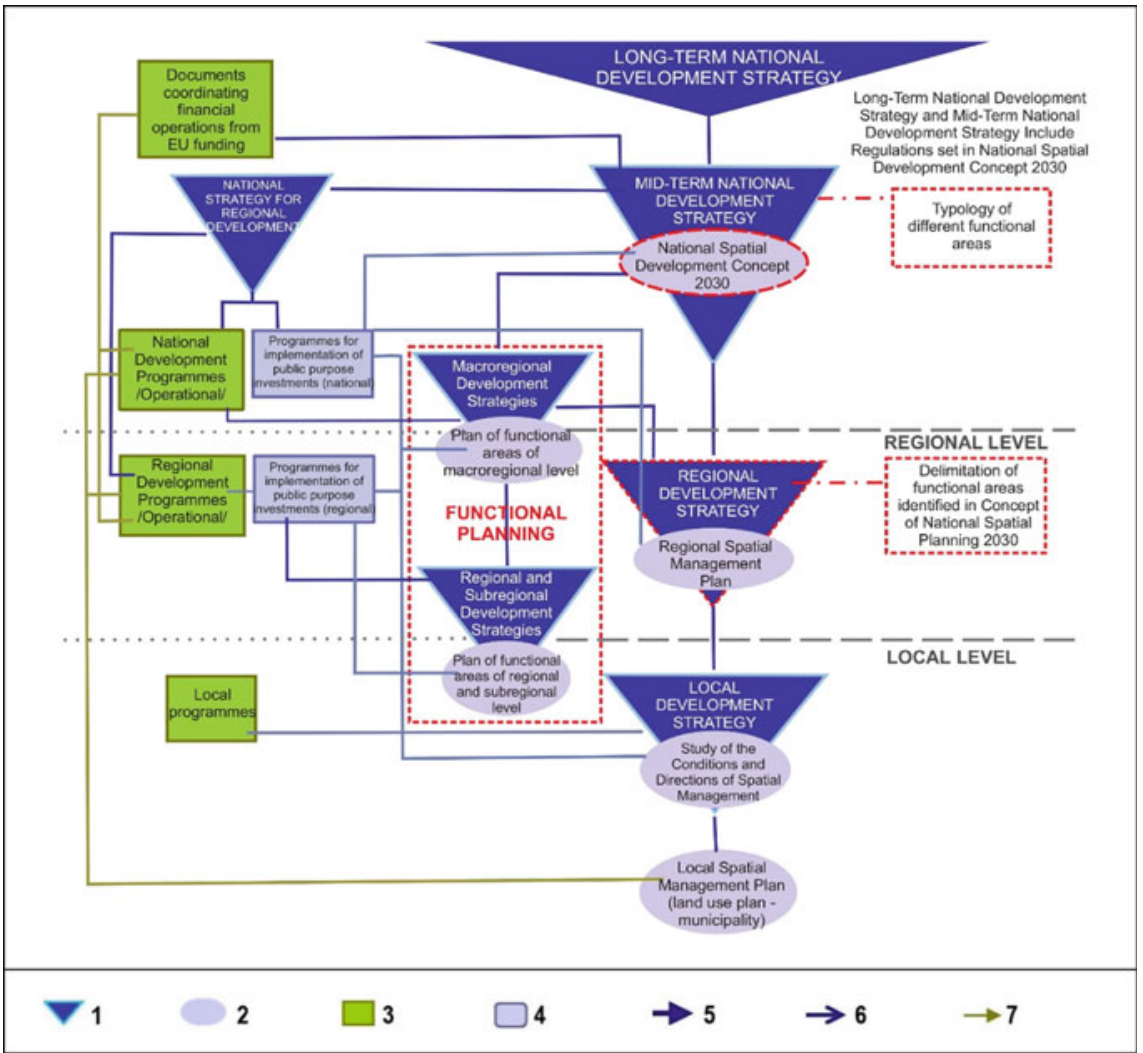

Fig. 4 Target hierarchical spatial-planning system in Poland: (1) strategic plans; (2) urban plans; (34) investments on national and regional level; (5) main planning direction; (6) functional planning; (7) operational planning. Source National Spatial Development Concept 2030

strategies for functional areas at the national, macro-regional, and regional levels. The coherence of socioeconomic planning with spatial planning at the regional level should ensure the requirement to harmonize both their content and the preparation method.

At the local level, the main document remains the local spatial development plan, consistent with the study of conditions, and directions of spatial development of the municipality. The study, as a document expressing the spatial policy of the commune, should also bring together all other documents and all decisions issued in the commune in relation to space management and land-use changes. It should also include tasks arising from strategic documents that pursue long-term local development goals, as long as they do not conflict with the documents of socioeconomic and spatial development at the national and regional level, the findings of which must also be included in the study documents and plans for development and implementation. 


\section{Discussion and Conclusion}

The review of post-war planning studies and documents on a national scale indicates an evolution of the approach to spatial planning, focused on integration with other planning sectors, i.e., economic, social, environmental, and cultural planning. This manner of performing the planning procedures was used in the currently binding document_- "National Spatial Development Concept 2030." This document derives directly from legal acts, where the scope of the document is defined as: (1) the distribution of basic elements of the national settlement network, with the separation of metropolitan areas and problematic zones; (2) the distribution of social amenities, technical infrastructure and transport facilities and water management facilities; (3) other elements of the spatial structure; and (4) environmental protection elements with their regulations, including protected areas. This approach is an expression of the pursuit of broadly understood strategic integrated planning-a long-term process in which it is necessary to integrate various fields and levels of planning, which will give a better chance to achieve sustainable goals of development.

Further development of urban-planning documents must include the demands of the ongoing global debate on changes in regional and national spatial policy. The currently binding documents have many features that make it possible to consider them as modern and corresponding to contemporary challenges emphasized by the OECD and EU institutions. These features include linking the regional development strategies with spatial policy issues and considering it as an immanent part of the country's long-term development strategy; strengthening connections between major cities, which favors the emergence of synergy effects, also in terms of the best chance to create a knowledge-based economic structures, and obtaining a competitive position among the regional networks of metropolitan centers in Europe; and approaching environmental issues with greater emphasis on the need to include sustainable development principles in spatial development strategies, which is particularly important in the context of climate change. These demands are implemented in a new document in the perspective of 2030 .

Its introduction to practice will require: changing provisions in the law; strengthening the authority of national and regional planning, so far weakly associated with local planning and implementing functional areas in planning practice that have a chance to develop more evenly throughout the country (metropolitan areas): making better use of existing potential (protection areas); protecting resources from misuse (water deficit areas); providing a basis for building future capacity (coastal zone); and adapting activities in accordance with the analysis of the state of development and functional connections (areas with poor time accessibility, rural areas).

As the analysis has shown, the assumptions of the "National Spatial Development Concept 2030" regarding the need to preserve the principle of joint control and subsidiarity with respect to determining responsibility for drawing up spatial development plans for functional areas are represented in correct a manner regarding the existing conditions. Their delimitation and the setting of planning standards and 
planning procedures as guidelines should be carried out with the participation of national, regional, and local entities, to find optimal and universal solutions.

\section{References}

Boentje JP, Blinnikov MS (2007) Post-Soviet forest fragmentation and loss in the Green Belt around Moscow, Russia (1991-2001): a remote sensing perspective. Landscape Urban Plann 82(4):208-221. https://doi.org/10.1016/j.landurbplan.2007.02.009

Borsa M (2015) Polityka przestrzenna w Polsce w latach 2004-2013. In: Strzelecki Z (ed) Wybrane regionalne i lokalne polityki publiczne w Polsce. 10 lat doświadczeń w warunkach członkostwa w Unii Europejskiej, Warszawa, pp 41-66

Chmielewski JM (2006) Planowanie przestrzenne w Polsce Ludowej 1945-1989. In: Chmielewski JM (ed) Warszawa odbudowana czy przebudowana? Planowanie przestrzenne w Polsce ludowej 1945-1989, Warszawa

Czerny W (1972) Architektura zespołów osiedleńczych. Arkady, Warszawa

Fijałkowski T (1994) Prawo budowlane, komentarz, akty wykonawcze. Sagal Ltd., Warszawa

Grabowiecki R, Zawadzki SM (1978) Planowanie struktury osadnictwa jako element planu krajowego. In: Malisz, B. 40 lat planowania struktury przestrzennej Polski. PWN Warszawa, pp 145-154

Hsu WT, Holmes TJ, Morgan F (2014) Optimal city hierarchy: a dynamic programming approach to central place theory. J Econ Theor 154:245-273. https://doi.org/10.1016/j.jet.2014.09.018

Jędraszko A (1981) Plany struktury. PWN Warszawa, Łódź

Jędraszko A (2005) Zagospodarowanie przestrzenne w Polsce—drogi i bezdroża regulacji ustawowych. PLATAN, Warszawa

Kachniarz T, Niewiadomski Z (1994) Nowe podstawy prawne zagospodarowania przestrzennego. Instytut Gospodarki Przestrzennej i Komunalnej, Warszawa

Mace A (2018) The Metropolitan Green Belt, changing an institution. Prog Plann 121:1-28. https:// doi.org/10.1016/j.progress.2017.01.001

Różański S (1979) Osadnictwo a środowisko Polski. PWN Warszawa

Secomski K (1978) Planowanie przestrzenne w systemie planowania rozwoju społecznogospodarczego. In: Malisz, B. 40 lat planowania struktury przestrzennej Polski. PWN Warszawa, pp 85-96

Toeplitz KL (1978) Pierwszy plan krajowy. In: Malisz, B. 40 lat planowania struktury przestrzennej Polski. PWN Warszawa, pp 23-40

Verdú-Vázquez A, Fernández-Pablos E, Lozano-Diez RV, López-Zaldívar Ó (2017) Development of a methodology for the characterization of urban and periurban green spaces in the context of supra-municipal sustainability strategies. Land Use Policy 69:75-84. https://doi.org/10.1016/j. landusepol.2017.08.040

Žlender V, Ward Thompson C (2017) Accessibility and use of peri-urban green space for inner-city dwellers: a comparative study. Landscape Urban Plann 165:193-205. https://doi.org/10.1016/j. landurbplan.2016.06.011 
Open Access This chapter is licensed under the terms of the Creative Commons Attribution 4.0 International License (http://creativecommons.org/licenses/by/4.0/), which permits use, sharing, adaptation, distribution and reproduction in any medium or format, as long as you give appropriate credit to the original author(s) and the source, provide a link to the Creative Commons license and indicate if changes were made.

The images or other third party material in this chapter are included in the chapter's Creative Commons license, unless indicated otherwise in a credit line to the material. If material is not included in the chapter's Creative Commons license and your intended use is not permitted by statutory regulation or exceeds the permitted use, you will need to obtain permission directly from the copyright holder.

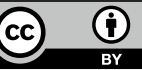

